\title{
Mary Anning's legacy to French vertebrate palaeontology
}

\author{
PEGGY VINCENT* $*_{\dagger}$, PHILIPPE TAQUET $\ddagger$, VALENTIN FISCHER $\S$, \\ NATHALIE BARDET $\ddagger$, JOCELYN FALCONNET $\ddagger$ PASCAL GODEFROIT \\ *Staatliches Museum für Naturkunde, Rosenstein 1, D-70191 Stuttgart, Germany \\ $\ddagger$ CR2P UMR 7207 CNRS-MNHN-UPMC, Département Histoire de la Terre, Muséum National d'Histoire Naturelle, \\ CP 38, 57 rue Cuvier, F-75231 Paris cedex 05, France \\ $\S$ Operational Directorate 'Earth and History of Life', Royal Belgian Institute of Natural Sciences, 29 Rue Vautier, \\ Brussels, Belgium \\ 9Département de Géologie, Université de Liège, B-18, Allée du 6 Août, Sart-Tilman, 4000 Liège, Belgium
}

(Received 1 January 2012; accepted 16 September 2013; first published online 29 October 2013)

\begin{abstract}
The real nature of marine reptile fossils found in England between the 1700s and the beginning of the 1900s remained enigmatic until Mary Anning's incredible fossil discoveries and their subsequent study by eminent English and French scientists. In 1820, Georges Cuvier acquired several ichthyosaur specimens found by Mary Anning, now kept or displayed in the Palaeontology Gallery of the Muséum National d'Histoire Naturelle (MNHN) in Paris. Four years later, Cuvier obtained a plesiosaur specimen from Mary Anning, only the second ever discovered. Cuvier was fascinated by these fossils and their study allowed him to apply his comparative anatomical method and to support his catastrophist theory. We have re-examined these important specimens from a historical point of view, and describe them here taxonomically for the first time since Cuvier's works. The Paris specimens belong to two different ichthyosaur genera (Ichthyosaurus and Leptonectes) and one plesiosaur genus (Plesiosaurus).
\end{abstract}

Keywords: Mary Anning, Georges Cuvier, Lower Jurassic, Ichthyosauria, Plesiosauria.

\section{Introduction}

By the early 1600s, an increasing number of isolated marine reptile remains found in England attracted the attention of naturalists and the popular press. These 'curios' were variously interpreted - although invariably misidentified - as the remnants of fishes or crocodiles and sometimes even whales or humans (e.g. Verstegan, 1605; Lhwyd, 1699; Scheuchzer, 1708; Stukely, 1719). The true nature of these fossils remained enigmatic until Joseph and Mary Anning discovered the first reasonably complete specimens of ichthyosaurs and plesiosaurs in southern England at the beginning of the nineteenth century.

Mary Anning (1799-1847) is recognized as the first female palaeontologist and one of the pioneers of this science in Europe. She became famous following her discoveries during 1811-1844 of the first almost complete specimens of ichthyosaurs and plesiosaurs in the marine strata of the Lower Jurassic of Lyme Regis, her native town. Mary and her older brother Joseph learned fossil collecting along the Dorset cliffs and beaches (which were already famous for their exceptional fossil richness and diversity) from their father. Both Mary and Joseph continued the family fossil business after their father's death (Torrens, 1995).

While Mary Anning unearthed fossils along the southern English coast, the French palaeontologist Georges Cuvier published a series of articles including one on the famous skull of "le grand animal fossile des

†Author for correspondence: pvincent@mnhn.fr carrières de Maestricht' (Cuvier, 1808), now known as Mosasaurus hoffmanni Mantell, 1829, and the first mosasaur to be named (see Bardet \& Jagt, 1996 for details). During the following years, Georges Cuvier purchased several marine reptile skeletons found by Mary Anning near Lyme Regis, which are now kept in the palaeontological collections of the Muséum National d'Histoire Naturelle (Paris). Most of these were studied by Cuvier himself. Surprisingly, and despite the fact that the history of these specimens was discussed by Taquet (2003), most of them were not subsequently reexamined. The aim of this study is therefore to provide both a historical review and appropriate re-descriptions of some of the material found by Mary Anning, subsequently studied by Georges Cuvier. The importance of these specimens is then discussed in the light of our current knowledge of Jurassic marine reptiles and the history of French vertebrate palaeontology.

\section{Materials}

\section{2.a. Institutional abbreviations}

GPIT - Geologisch-Paläontologisches Institut und Museum, Universität Tübingen, Germany; IRSNB - Institut Royal des Sciences Naturelles de Belgique, Bruxelles, Belgium; MNHN - Muséum National d'Histoire Naturelle, Paris, France; NHMUK - Natural History Museum, London, UK.

\section{2.b. Geological setting and stratigraphy}

All of the material described here was discovered within the lower part of the Lias Group (Lower 
Jurassic) sequence of shale and limestone beds exposed close to Lyme Regis, referred to as the Blue Lias. The lower Lias Group consists mostly of laminated black shale and mudstone beds that are often organic rich and interpreted as reflecting near-shore subanoxic to anoxic marine conditions (Wignall \& Hallam, 1991). This setting is the main reason behind the exceptional concentration and preservation of the Lyme Regis fauna (Lord \& Davis, 2010), within which marine reptiles are well represented.

The 'Lias' rock at Lyme Regis was quarried from the sea ledges in the early nineteenth century, mostly for cement making, an activity that provided numerous opportunities for fossil hunting. Most of the wellprovenanced ichthyosaurian and plesiosaurian remains from the Dorset coast are Sinemurian in age (e.g. Temnodontosaurus platyodon, Obtusum Zone, McGowan, 1994; Plesiosaurus dolichodeirus, Raricostatum Zone, Storrs, 1997). However, the stratigraphic origins of the specimens described here were not specified by Cuvier. The reptile-bearing Lower Lias strata near Lyme Regis span the Hettangian - lower Pliensbachian interval (Cope et al. 1980; Benton \& Spencer, 1995). As a result, the exact geological ages of Cuvier's material are therefore unknown.

\section{2.c. History of the specimens}

As Taquet (2003) mentioned, Georges Cuvier noted that his predecessors who were interested in studying extinct animals experienced two kinds of difficulties: the random nature of fossil occurrences and the infancy of comparative anatomy, which was then lacking sufficiently complete collections for comparisons. To overcome these difficulties and gather the scientific data necessary for his work, Cuvier offered an ingenious deal to his correspondents: in exchange for unpublished data, casts and original fossil remains, he could exchange information that he had in the form of documents, books and casts (Taquet, 2003). Cuvier addressed these requests to many European colleagues. Despite his regular correspondence with Sir Everard Home (since 1800), Cuvier had to wait until the end of the conflict between France and the United Kingdom and the Congress of Aix-la-Chapelle, ending the military occupation in 1818, to go to England (Taquet, 2003).

In 1818, Cuvier went to Oxford and London where he met Home. Cuvier took the opportunity to examine the remains of an ichthyosaur (not yet recognized as such at that time) that had been previously described by Home (1814). This specimen, the first partially complete ichthyosaur skeleton ever found, was unearthed by Joseph and Mary Anning in 1811. Cuvier found the remains intriguing and described them as follows:

\footnotetext{
'Nous voici arrivés à ceux de tous les reptiles, et peut-être de tous les animaux fossiles, qui ressemblent le moins à ce que l'on connoît, et qui sont le plus faits pour surprendre le naturaliste par des combinaisons de structures qui, sans aucun doute, paroîtroient incroyables à quiconque ne seroit
}

pas à portée de les observer par lui-même [...]' (Cuvier, 1824 , p. 445). 'We have come to those of all reptiles, and perhaps of all fossil animals, which resemble the least to what is known, and which are the most able to surprise the naturalist by combinations of structures that, without any doubt, seem incredible to anyone who would not be able to observe them by himself' (author translation).

He also noted that other as yet undocumented vertebrate fossils (including plesiosaur remains that he had observed in the Royal College of Surgeons) had been unearthed in England. From 1818 to 1824 Cuvier followed all the discoveries of new marine reptiles in England with great attention, especially those made in Lyme Regis by the Anning family. He rapidly managed to obtain casts and fine specimens of these marine reptiles, which formed an integral basis for Chapter V of his 'Recherches sur les Ossemens fossiles' (Cuvier, 1824).

In 1819 the Annings were in considerable financial difficulties (Torrens, 1995). They were rescued by the generosity of the fossil collector and former Life Guards officer Lieutenant-Colonel Thomas James Birch (1768-1829), who arranged for the sale of his personal collection, largely purchased from the Annings, in Bullock's Museum in London (Torrens, 1995). The Bullock's auction took place in May 1820, during which Cuvier bought several beautiful pieces for the Muséum National d'Histoire Naturelle (Taquet, 2003, p. 43). Little information is available about the price of these specimens. MNHN AC 9862 is known to have been purchased for $£ 14.14$, and femur (which could not be located in the MNHN collections) for $£ 1.10$ (Mantell, 1846; Torrens, 1979). Cuvier described and figured some of these specimens in his famous 'Recherches sur les Ossemens fossiles' (MNHN AC 9862, 9866, 9937, 9950, 9951 and 9935; Figs 1, 2; Cuvier, 1824). However, only five of these specimens could be found in the collections of the MNHN of Paris. The specimen MNHN AC 9935 should therefore be temporarily considered as lost.

One partial ichthyosaur skull bought by Cuvier (MNHN AC 9862; Fig. 1a-d) was previously described and figured by Home $(1819 a, b)$. In his description, Home (1819a) thanked De la Beche and Birch for procuring material, which allowed him to correct some errors that the 'imperfect state of the first specimens' had led him to commit. From the observation of MNHN AC 9862, Home attributed the 'aperture' (external nares) he had described and delineated in his first paper to taphonomic artefacts. The absence of external nares is one of the pieces of evidence used by Home (1819b) to state that this animal - for which he proposed the name Proteosaurus - was intermediate between fishes and lizards. When Cuvier re-examined this specimen, after having prepared it adequately, he confirmed that the supposed breaks were actually the external nares, and also found the parietal foramen.

In December 1823, Mary Anning found an almost 3-m-long animal with a small head that is now recognized as the first partial plesiosaur skeleton. In March 

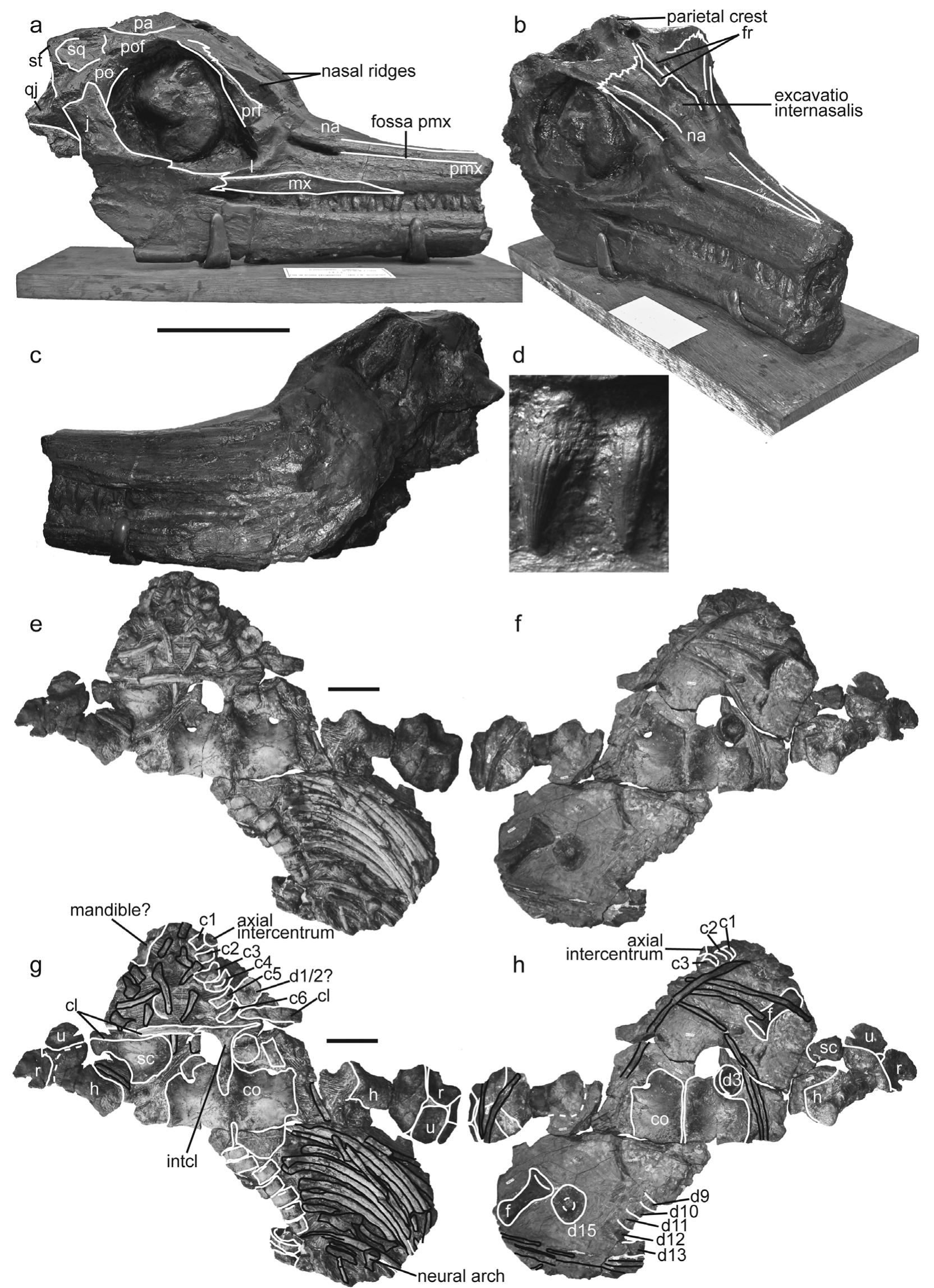

Figure 1. MNHN AC 9862, Ichthyosaurus cf. communis from the Lower Lias of England; skull in (a) right lateral view, (b) oblique view, (c) left lateral view and (d) close-up of the teeth. MNHN AC 9937, Leptonectes tenuirostris from the Lower Lias of England; post-cranial skeleton in $(e, g)$ ventral view and $(f, h)$ dorsal view. Abbreviations: c - cervical vertebra; co - coracoid; $d$ - dorsal vertebra; $\mathrm{f}$-femur; fr - frontal; h - humerus; intcl-interclavicle; $\mathrm{j}$ - jugal; 1 - lacrimal; $\mathrm{mx}$ - maxilla; na - nasal; pa - parietal; pmx - premaxilla; po - postorbital; pof - postfrontal; prf - prefrontal; qj - quadratojugal; $r$ - radius; sc - scapula; sq - squamosal; st - supratemporal; $\mathrm{u}-$ ulna. Scale bars: $10 \mathrm{~cm}$. 
1824, Cuvier received a letter from Georges Cumberland including a sketch of the specimen (Taquet, 2003). The strange and unexpected proportions (long neck v. short head) of this new animal led him to suspect that it might be a composite. He advised Conybeare to make sure that this was not the case. He also said:

'Cette découverte, en ce cas, surpasse toutes celles que l'on a faites jusqu'ici, et il n'y a rien de si monstrueux que l'on ne doive s'attendre à voir sortir des carrières du Lias' (letter from Cuvier to Conybeare, 1824). 'This discovery, in this case, surpasses all those that have been made so far, and there is nothing more monstrous that one could expect to see coming from the Lias quarries' (author translation).

A few days later, he received letters from Buckland and Conybeare including anatomical details, drawings, an engraving of the specimen from Buckland and a sketch made by Mary Morland (Buckland's wife-tobe) from Mary Anning's own drawings. They managed to convince Cuvier that this specimen was a genuine find. From that moment forward, Cuvier treated Mary Anning as a legitimate and respectable fossil collector and cited her name in his publications (e.g. Cuvier, 1824, p. 473).

In order to acquire new specimens for the MNHN, Cuvier decided to send the French geologist Constant Prévost (1787-1856) to Great Britain for an official geological trip, supported by the administration of the museum. In May 1824, Prévost was received by the famous British geologist Charles Lyell and embarked on a long geological trip through England with him. They went to Lyme Regis, probably in June 1824, and met Mary Anning. Slightly before his arrival, Royal Navy Captain Waring (an amateur palaeontologist) discovered a plesiosaur specimen (Anonymous, 1824, p. 92; Taquet, 2003, p. 58) that was subsequently bought by Mary Anning for £3 (Gosselet, 1896 cited by Taquet, 2003). During his stay at Lyme Regis, Prévost bought this plesiosaur (MNHN AC 8592; Fig. 3c-e) from Mary Anning for $£ 10$ and sent it to Paris (Taquet, 2003). It is the second partially complete plesiosaur specimen ever discovered. The history of MNHN AC 8592 shows that Mary Anning was not only a skilful palaeontologist, but also a keen businesswoman. It was probably sold after some preparation in order to increase the attractiveness of the specimen and to sell it for a higher price.

In 1825 , Cuvier published a third edition of his ' $D i s-$ cours sur les révolutions de la surface du globe'. This was the opportunity for him to include the engraving of his plesiosaur from Mary Anning (Cuvier, 1825, pl. III, fig. 1). He also added to the engraving the head and neck of the first complete specimen of Plesiosaurus, as published by Conybeare (1824), then bought by the Duke of Buckingham and later given to the British Museum of Natural History (now NHMUK PV OR22656). MNHN AC 8592 has been on display in the Gallery of Palaeontology since 1898. It was recently described extensively by Vincent \& Taquet (2010). Prévost also presented the partial mandible of a plesiosaur
(MNHN AC 8581; Fig. 3d, e), presumably found associated with MNHN AC 8592, to the MNHN. This bone was figured by Gaudry (1890, fig. 270), but does not appear in Cuvier's (1825) book. The existence of this specimen was unknown to Vincent \& Taquet (2010) when they re-described MNHN AC 8592 and has therefore never been described appropriately, a task undertaken here (see Section 3).

\section{Description}

\section{3.a. Ichthyosaurs}

Systematic Palaeontology

Ichthyosauria Blainville, 1835

Parvipelvia Motani, $1999 b$

Neoichthyosauria Sander, 2000

Leptonectidae Maisch, 1998

Leptonectes McGowan, 1996

Leptonectes tenuirostris (Conybeare, 1822)

Referred specimen: MNHN AC 9937, a partial postcranial skeleton including 20 presacral vertebrae, ribs, pectoral girdle, both humeri, ulnae, radii and femora (Fig. 1e-h). Cuvier has figured the ventral aspect of the specimen. The dorsal view is figured and described here for the first time.

Remark: MNHN AC 9937 was referred to Ichthyosaurus by Cuvier (1824, p. 105, pl. XXX, fig. 1).

Description: The specimen MNHN AC 9937 mainly comprises postcranial remains, but indeterminate bones located just anterior to the atlas-axis complex could correspond to the mandible. The atlas-axis complex is sutured, with the conical axial intercentrum preserved disarticulated next to it. In addition to the atlas and axis, four typically pentagonal cervical and 14 rounder dorsal vertebrae are preserved in ventral view.

The pectoral girdle comprises the almost-complete coracoids, clavicles, interclavicle and the right scapula. The latter is a short robust element consisting of a strap-like shaft and flared extremities. The ventral end is curved and broadly expanded. The dorsal end is not preserved. Ventrally, the scapula expands into a large facet for the reception of the coracoid. Its anterior border is straight while its posterior border is curved, unlike the condition seen in Temnodontosaurus, Ichthyosaurus and Stenopterygius (Maisch \& Matzke, 2000a; Caine \& Benton, 2011). A large, flat acromial process is present anteriorly as in Stenopterygius (Johnson, 1979), ophthalmosaurids (Maxwell \& Druckenmiller, 2011; Fischer et al. 2012), Leptonectes (McGowan \& Milner, 1999; McGowan \& Motani, 2003) and Excalibosaurus (McGowan, 2003). The coracoid is a broad platelike element with wide anterior and posterior notches. The intercoracoid facet is thick and ellipsoidal. The scapular facet is small and faces anterolaterally while a larger facet, facing laterally, corresponds to the 
coracoidal contribution to the glenoid cavity. Anteriorly, a deep and narrow notch is present as in Eurhinosaurus (Maisch \& Matzke, 2000a). It is clearly narrower than that observed in I. communis and Temnodontosaurus sp. (McGowan \& Motani, 2003). The clavicles are slightly disarticulated, but the right clavicle follows the edge of the scapula up to its distal end. The anterior and posterior margins extend parallel to each other and become narrower medially. Unlike other specimens of Ichthyosaurus (Maisch \& Matzke, $2000 a$ ), the interclavicle is markedly T-shaped with a long and slender median bar.

Both incomplete forelimbs are preserved in approximately their natural positions, although the right forelimb is preserved on the opposite side (i.e. dorsally) compared to the rest of the elements preserved on the block in ventral view. The shaft of the humerus is long, constricted and concave anteriorly and posteriorly. The humerus is markedly expanded distally; it therefore differs from that of Eurhinosaurus, Suevoleviathan and I. communis (Maisch \& Matzke, 2000a), Malawania (Fischer et al. 2013) and some species of Temnodontosaurus (Martin et al. 2012). Its deltopectoral crest is robust. Distally, the radial and ulnar facets are subequal in size. The radius is sub-hexagonal and broader than long. It is notched at the midpoint of its preaxial edge, as in Leptonectes, Temnodontosaurus, Eurhinosaurus and Stenopterygius (Maisch \& Matzke, 2000a; McGowan $\&$ Motani, 2003). The radius is marginally wider than the ulna. The ulna is hexagonal in outline and bears a prominent humeral articular facet. The radius and ulna enclose a foramen; similar spatia interossea are only present in Triassic ichthyosaurs and Leptonectes tenuirostris (Godefroit, 1992; Maisch \& Matzke, 2000b), although some specimens referred to as Temnodontosaurus have been reported with an anterior notch on the ulna (McGowan, 1996).

The femora have a short and narrow shaft, being longer than wide, as in many non-ophthalmosaurid parvipelvians (Martin et al. 2012), and expand at both extremities. The anterior and posterior margins are concave. Its proximal facet is rounded, whereas its distal end is concave without separate tibial and fibular facets.

Identification: The presence of a large acromial process of the scapula, of a spatium interosseum enclosed by the radius and the ulna and the general shape and proportions of the propodials of MNHN AC 9937 is a combination of features unique to Leptonectes tenuirostris (McGowan \& Motani, 2003).

\section{cf. Leptonectes}

Referred specimen: MNHN AC 9866, a threedimensionally preserved skull, consisting of the posterior half of the cranium preserved from the posterior margin of the naris (Fig. 2 a-d).

Remark: MNHN AC 9866 was referred to Ichthyosaurus intermedius by Cuvier (1824, p. 456, pl. XXIX, figs 2-5).
Description: The maxilla forms the ventral border of the external naris as in some specimens of Stenopterygius triscissus (Godefroit, 1993b, 1994; McGowan \& Motani, 2003; Maisch, 2008), Leptonectidae (Maisch \& Matzke, 2000b) and Suevoleviathan disinteger (Maisch, 2001). A great part of the posterior portion of the nasal is preserved. There is no processus narialis, unlike the condition seen in Stenopterygius cf. quadriscissus (Maisch \& Ansorge, 2004). Posteriorly, the nasal overlaps the prefrontal laterally and contacts the frontal posteromedially. The frontals do not split the nasal medially in contrast to Leptonectes tenuirostris (Maisch \& Matzke, 2000a, 2003) and Stenopterygius (e.g. Motani, 2005; Caine \& Benton, 2011). The lacrimal appears less extensive than that of $I$. communis (Maisch \& Matzke, 2000b). Dorsally, the lacrimal contacts the prefrontal but is separated from the nasal by a process of the prefrontal, as in Leptonectes tenuirostris and Ichthyosaurus breviceps (Maisch \& Matzke, 2000b, 2003). The jugal is slender and elongate. Its anterior end extends up to the level of the external naris as in Temnodontosaurus, but unlike the condition observed in Ichthyosaurus, Stenopterygius and Suevoleviathan (Maisch \& Matzke, 2000a). Its posterior end is thick and excluded from the orbital margin by the postorbital as in Suevoleviathan, I. intermedius and I. communis (Maisch \& Matzke, 2000a). The frontal contacts the nasal anteriorly, the prefrontal laterally and the parietal posteriorly. It forms the anterior margin of the parietal foramen. The parietal foramen is noticeably bilobed and consists of a broad and teardropshaped anterior portion and a larger well-rounded posterior extension bordered by the parietals. A similar structure (albeit much smaller) has been described in 'Ichthyosaurus zetlandicus' Seeley, 1880 and in the Albian ophthalmosaurid Athabascasaurus (Druckenmiller \& Maxwell, 2010). However, in both cases the parietal foramen does not reach the impressive extension of MNHN AC 9866. The Late Jurassic ophthalmosaurid Palvennia hoybergeti (Druckenmiller et al., 2012) also possesses an enlarged parietal foramen; the taxonomic value of this feature is currently unknown. The postorbital is poorly preserved. It is wide and forms the posterodorsal and posterior margin of the orbit. The anterior extremities of the medial and lateral rami of the supratemporal are uncertain. The ventral ramus is massive at its dorsal end, but poorly preserved. On the left side, it articulates with the opisthotic ventromedially. The dorsal portion of the quadrate articulates with the supratemporal. The occipital condyle is relatively flat and is offset from the body of the basioccipital by a narrow, shallow groove. The extracondylar area of the basioccipital is well developed, as in non-ophthalmosaurid ichthyosaurs (Motani, 1999b). The opisthotic forms a broad contact with the basioccipital medially. Its morphology is difficult to discern. The interpterygoid vacuities are well developed with the medial margin of the pterygoid slightly concave.

The incomplete sclerotic ring is preserved in articulation, filling the entire vacuity of the orbit as in juvenile 


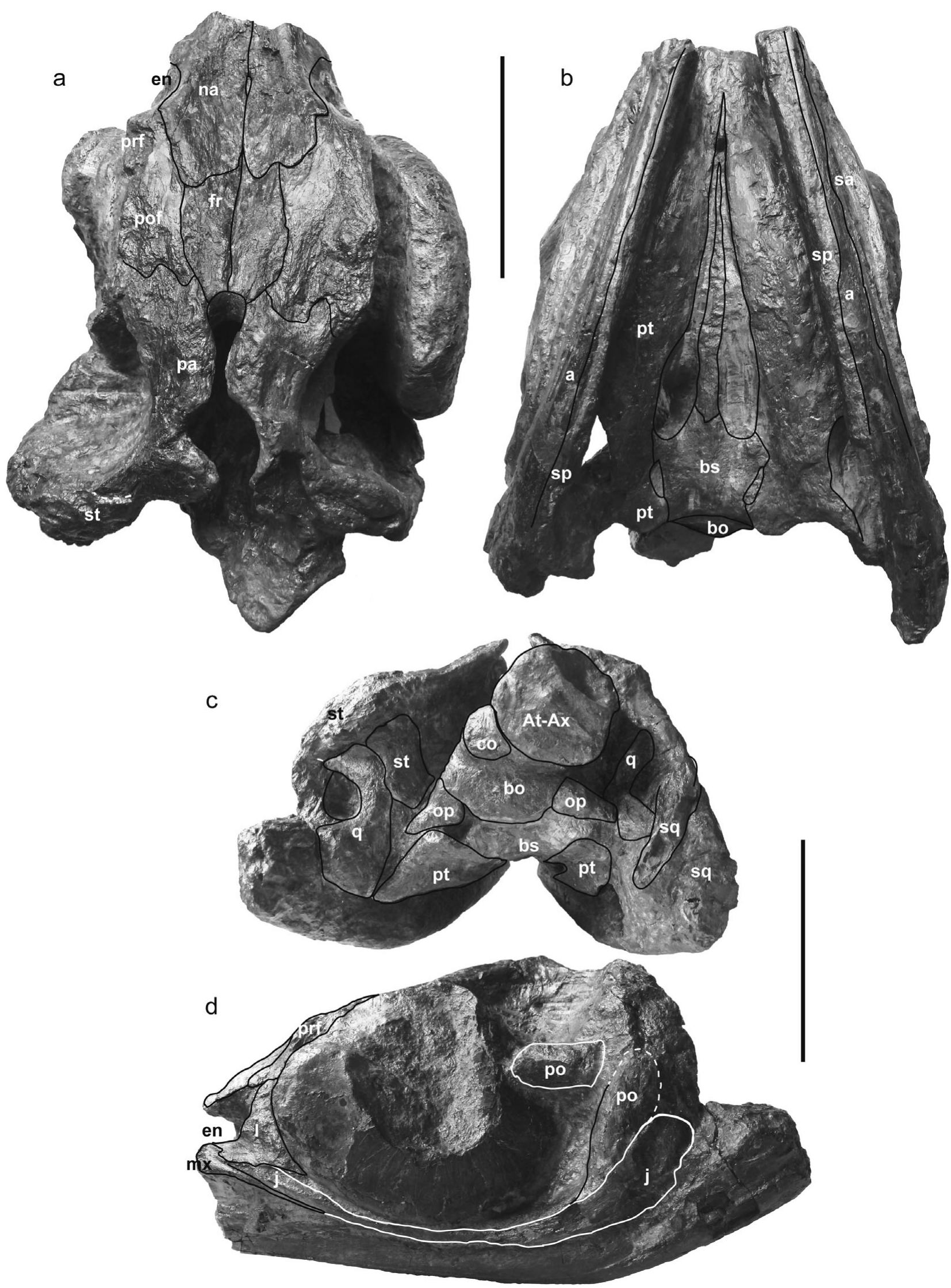

Figure 2. MNHN AC 9866, cf. Leptonectes from the Lower Lias of England, skull in (a) dorsal view, (b) ventral view, (c) posterior view and (d) left lateral view. Abbreviations: a - articular; At-Ax - atlas-axis complex; bo - basioccipital; bs - basisphenoid; co - occipital condyle; en - external naris; fr - frontal; $\mathrm{j}$ - jugal; 1 - lacrimal; mx - maxilla; na - nasal; op - opistotic; pa - parietal; po - postorbital; pof - postfrontal; prf - prefrontal; pt - pterygoid; q - quadrate; sa - surangular; sp - splenial; sq - squamosal; st supratemporal. Scale bars: $10 \mathrm{~cm}$. 
ichthyosaurs (Fernández et al. 2005; Kear \& Zammit, 2013) and adult leptonectids (e.g. Huene, 1951; Maisch \& Matzke, 2000b, 2003; McGowan, 2003; McGowan \& Motani, 2003; Maisch \& Reisdorf, 2006; Reisdorf, Maisch \& Wetzel, 2011). The orbit appears large relative to skull size; the jugal and postorbital bones are reduced and slender, as in Leptonectidae (e.g. Maisch \& Matzke, 2003) and Hauffiopteryx (Maisch, 2008; Caine $\&$ Benton, 2011) and unlike the condition seen in Temnodontosaurus (e.g. McGowan \& Motani, 2003), Suevoleviathan (Maisch, 2001) and Ichthyosaurus (Maisch $\&$ Matzke, 2000a). The mandible is large and appears unreduced compared to the upper jaw, unlike in $E x$ calibosaurus and Eurhinosaurus (McGowan, 2003).

Identification: Close comparisons with the ichthyosaurs from the Lower Jurassic of Europe indicate that MNHN AC 9866 does not belong to the following genera. (1) Temnodontosaurus species possess a nasal that extends far above the orbit to meet the parietal (Maisch et al. 2008), contrasting with MNHN AC 9866 in which the nasal is clearly separated from the parietal by the prefrontal and frontal. (2) Ichthyosaurus species possess a contact between the lacrimal, the prefrontal and the nasal dorsally (except I. intermedius; Maisch \& Matzke, 2000a). The nasal does not contact the lacrimal in MNHN AC 9866. Moreover, the jugal does not extend up to the level of the external naris anteriorly in Ichthyosaurus (Maisch \& Matzke, 2000a). This condition is clearly present in MNHN AC 9866. (3) Among leptonectids, Eurhinosaurus possesses a foramen parietal bordered by the nasal (Maisch \& Matzke, 2003), a condition not observed in MNHN AC 9866. MNHN AC 9866 closely resembles leptonectids and especially Leptonectes because of the relatively large orbit and sclerotic ring, maxilla forming the ventral border of the naris, long parietal-prefrontal contact and retention of an unreduced mandible. However, the peculiar shape of the parietal foramen has never been described in any other ichthyosaur taxa except in the Late Jurassic ophthalmosaurid Palvennia hoybergeti (Druckenmiller et al. 2012). MNHN AC 9866 could therefore belong to a new taxon; more material and/or a thorough re-evaluation of the cranial features of Liassic ichthyosaurs are needed to confirm or refute this hypothesis.

Thunnosauria Motani, $1999 b$

Ichthyosauridae Gray, 1825

Ichthyosaurus De la Beche \& Conybeare, 1821 Ichthyosaurus communis De la Beche \& Conybeare, 1821

Ichthyosaurus cf. communis

Referred specimen: MNHN AC 9862, a large skull lacking the anterior half of the rostrum and left posterolateral side (Fig. 1a-d).

Remark: MNHN AC 9862 was referred to Proteosaurus by Home (1819a, p. 215, pl. XIII) and Ichthyosaurus communis by Cuvier (1824, p. 456, pl. XXIX, fig. 1).
Description: The premaxilla lacks a conspicuous fossa praemaxillaris, as in Ichthyosaurus intermedius (Maisch, 1997b), but forms a deep sulcus anterior to the naris. A processus supranarialis is present, forming the anterior half of the dorsal margin of the naris. The posterior extent of the premaxilla ventral to the naris is unknown, as the suture with the lacrimal is not preserved.

The maxilla has a low dorsoventral lateral exposure and does not contribute to the edge of the naris, unlike in Stenopterygius 'longifrons' (equivalent to triscissus; Godefroit, 1993a, 1994; McGowan \& Motani, 2003; Maisch, 2008; although some specimens of $S$. triscissus lack this feature; Caine \& Benton, 2011), Suevoleviathan disinteger (Maisch, 2001) and Leptonectidae (Maisch \& Matzke, 2000a). The anterior part of the maxilla is quite reduced in lateral view, extending a few centimetres anterior to the level of the naris unlike the elongated process found in Temnodontosaurus (Godefroit, 1993b; McGowan \& Motani, 2003; personal observation of V.F. on NHMUK PV OR2003, NHMUK PV R1158 and NHMUK PV R1157).

The nasal is long and prominent, the latter feature probably a result of diagenetic transverse compression of the skull. Nevertheless, the nasal forms a long anteroposterior ridge laterally. Medially, the nasals form a narrow yet deep excavatio internasalis, as in all neoichthyosaurians (Maisch \& Matzke, 2000a). This sulcus probably also extends onto the frontal, and appears very similar to that described in a large specimen referred to Ichthyosaurus communis (SMF 46; Maisch et al. 2008). As in the latter species (e.g. Godefroit, 1996), the posterior part of the nasal of MNHN AC 9862 forms an extensive fan-shaped sheet that covers - rather than articulating in the same plane as - the prefrontal, the frontal and the postfrontal. The state of preservation does not permit us to assess the presence or absence of an internasal foramen.

The lacrimal, the prefrontal and the postfrontal are poorly preserved and appear to have been restored to some extent; accordingly, these elements will not be described here. As seems to be the case in most non-ophthalmosaurid parvipelvians (e.g. McGowan \& Motani, 2003; Maisch et al. 2008), the frontal has a reduced dorsal exposure and is lanceolate. It is unclear whether it participates in the parietal foramen or not.

The dorsal surface of the parietal is concave, forming a prominent parietal crest. Anteromedially, the parietal has a large, round parietal foramen. This region is poorly preserved so it is impossible to know if the prefrontal contacts the parietal as described in Ichthyosaurus and Stenopterygius triscissus by Motani (2005).

Three bones are present in the lateral part of the temporal region of MNHN AC 9862: the supratemporal, the postorbital and the squamosal, arranged as in Ichthyosaurus communis (Maisch \& Matzke, 2000 b) and Stenopterygius cf. quadriscissus (Maisch \& Ansorge, 2004). The postorbital is anteroposteriorly 
long compared to Leptonectidae (Motani, 1999b; Maisch \& Matzke, 2003). It contacts the supratemporal anteromedially and is covered posterodorsally by a thin bone layer. We interpret this bony sheet as the squamosal, as it bears close resemblance in shape and position to that of Ichthyosaurus communis (Maisch $\&$ Matzke, 2000b) and to a lesser extent that of Temnodontosaurus platyodon (McGowan, 1994) and Temnodontosaurus trigonodon (Maisch \& Hungerbühler, 2001). Although the suture between the supratemporal and the squamosal cannot be adequately identified dorsally, it is apparently present anteriorly and posterodorsally. The shape of the squamosal differs from that of Suevoleviathan spp. (Maisch, 1998, 2001), Leptonectes (Maisch \& Matzke, 2003) and Eurhinosaurus (Huene, 1951), where it is markedly elongated dorsoventrally.

The posterior part of the jugal is thick, appearing much more robust than in Ichthyosaurus breviceps and I. conybeari (McGowan, 1974b) and some specimens of Ichthyosaurus communis, such as GPIT 1796/1 (Maisch \& Matzke, 2000b; Lomax, 2010; Bennett et al. 2012). The Bonnert specimen of I. communis (IRSNB R145, Belgium; Godefroit, 1996) possesses a jugal similar to that of MNHN AC 9862, however. The quadratojugal is raised dorsally with respect to the rest of the postorbital and does not contact the jugal extensively, creating an embayment as in most non-baracromian ichthyosaurs with the exception of Shastasaurus pacificus (Sander et al. 2011), T. trigonodon (Maisch \& Hungerbühler, 2001), Suevoleviathan spp. (Maisch, 1998, 2001) and 'Ichthyosaurus zetlandicus' (Seeley, 1880; referred to Stenopterygius by Huene, 1922 and to Temnodontosaurus by Maisch, $1997 a$ who later considered it as probably belonging to a new genus; Maisch, 2010).

The mandible is poorly preserved and lacks any noteworthy features. In contrast to the premaxilla, the dentary possesses a continuous fossa dentalis, as in Ichthyosaurus breviceps (Massare \& Lomax, 2013). The teeth are robust and conical, unlike in Leptonectidae (e.g. Huene, 1922; Motani, 1999b), Stenopterygius and Hauffiopteryx (e.g. Fraas, 1891; Godefroit, 1994). The crown is textured by deep apicobasal ridges and lacks carinae, unlike in T. platyodon (Godefroit, 1993b), T. eurycephalus (personal observation by V.F. on holotype NHMUK R1157) and some specimens of T. trigonodon (Theodori, 1843; Fraas, 1891). All apicobasal ridges on the crown continue to the root, deepening and diverging basally. This peculiar tooth ornamentation is only found in Ichthyosaurus communis (Massare, 1987; Godefroit, 1996; Maisch \& Matzke, 2000b) and some specimens of Temnodontosaurus (Godefroit, 1993b). Within the genus Ichthyosaurus, the absence of a smooth 'neck' between the crown and the root (most probably an acellular cementum ring; see Maxwell, Caldwell \& Lamoureux, 2011, 2012 for a detailed analysis of ichthyosaur teeth) differs from I. intermedius (Maisch, 1997b), I. breviceps (personal observation by V.F. on NHMUK PV OR39263) and
Pliensbachian specimens of Ichthyosaurus (Lomax, 2010; Bennett et al. 2012).

Identification: Because the taxonomy of Early Jurassic ichthyosaurs is based traditionally on phenetic ratios and forefin architecture (McGowan, 1974a, b, 1979; Appleby, 1979; McGowan \& Motani, 2003; Maxwell, 2012), skull features have received comparatively less attention (but see McGowan, 1973; Maisch, 1997b, 2001, 2002; Maisch \& Hungerbühler, 1997; Maisch \& Matzke, 2002; Motani, 2005; Maisch et al. 2008). Accordingly, autapomorphic cranial features have rarely been identified. However, a combination of traits permits preliminary differentiation of taxa. These 'shared' character states were detailed in the description above, so only a summary in the form of a differential diagnosis is provided here.

MNHN AC 9862 differs from Leptonectidae, Stenopterygius, Hauffiopteryx typicus, Ichthyosaurus breviceps, Ichthyosaurus conybeari and Ichthyosaurus intermedius in having a robust rostrum and large teeth with deep and continuous apicobasal striations. The ornamentation of the teeth and the shape of the squamosal differ from the condition seen in Suevoleviathan (Maisch, 1998). The lack of carinae differs from Temnodontosaurus platyodon (Godefroit, 1993b), Temnodontosaurus trigonodon (Theodori, 1843) and Temnodontosaurus eurycephalus (personal observation by V.F. on holotype NHMUK R1157). The possession of an embayment between the jugal and the quadratojugal differs from Temnodontosaurus trigonodon (Maisch \& Hungerbühler, 2001), Stenopterygius (Godefroit, 1993a, 1994; Maisch \& Ansorge, 2004) and Suevoleviathan (Maisch, 2001). While the poorly known taxa Temnodontosaurus acutirostris (Maisch \& Matzke, 2000a; Maisch, 2010), Temnodontosaurus crassimanus (McGowan \& Motani, 2003; Maisch, 2010) and Temnodontosaurus nuertingensis (Maisch \& Hungerbühler, 1997) cannot be ruled out of the list of possibilities except on the basis of size and stratigraphic age differences, we consider the close resemblance between MNHN AC 9862 and Ichthyosaurus communis as sufficient evidence for an assignment to this taxon. However, as this identification is made by default, we refer this specimen to Ichthyosaurus cf. communis.

\section{Ichthyosaurus sp.}

Referred specimens: MNHN AC 9950, a partial axial skeleton with complete ?left forefin (Fig. 3a); MNHN AC 9951, a partial shoulder girdle with nearly complete left forefin (Fig. 3b).

Remark: MNHN AC 9950 was referred to Ichthyosaurus by Cuvier (1836, p. 105, pl. XXX, figs 2, 3).

Description: MNHN AC 9950: Ten thoracic centra are preserved. The diapophyses and parapophyses are prominent and are set in a median position, suggesting they originate from the middle trunk region. 

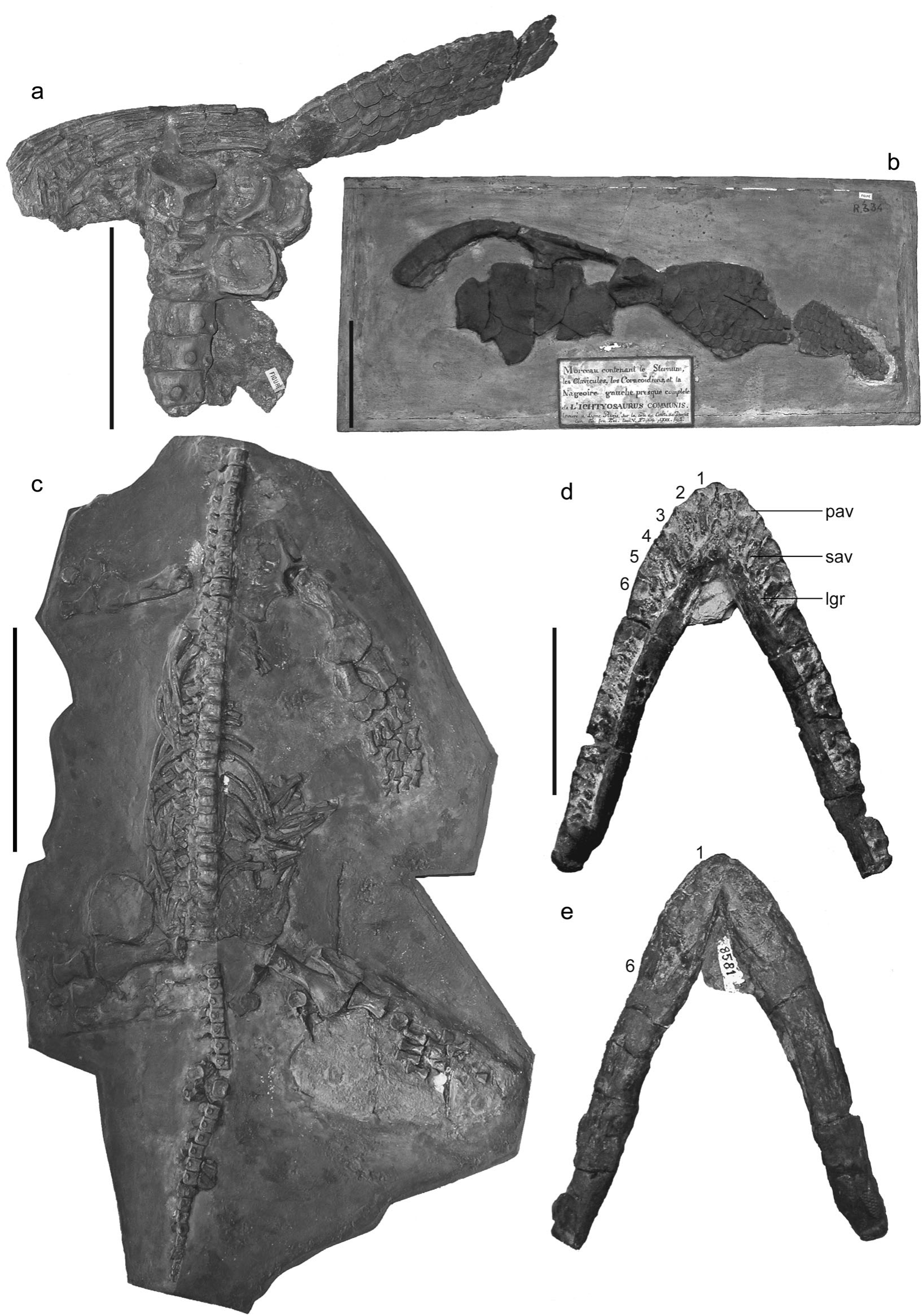

Figure 3. (a) MNHN AC 9950, Ichthyosaurus sp. from the Lower Lias of England, post-cranial remains. (b) MNHN AC 9951, Ichthyosaurus sp. from the Lower Lias of England, post-cranial remains. (c) MNHN AC 8592, Plesiosaurus dolichodeirus from the Lower Lias of England, post-cranial skeleton. (d, e) MNHN AC 8581, Plesiosaurus dolichodeirus from the Lower Lias of England, mandible in (d) dorsal and (e) ventral view. Abbreviations: lgr - lateral groove; pav - primary alveoli; sav - secondary alveoli. Scale bars: (a, b) $10 \mathrm{~cm}$, (c) $50 \mathrm{~cm}$ and (d, e) $5 \mathrm{~cm}$. 
Fragmentary ribs are preserved. Some fragments possess the typical thunnosaurian groove (Sander, 2000) that gives the rib an eight-shaped cross-section. The forefin (presumably the left one) is nearly complete, but the humerus and the epipodial row are poorly preserved and covered by the centra. The forefin is similar to that of Ichthyosaurus: (1) it has a 'latipinnate' architecture (two digits arise from the intermedium; McGowan, 1974b); (2) secondary digital bifurcation occurs (Motani, 1999a) from the metacarpal of the third digit and from the third phalange of the second (leading-edge) digit, giving a total of six digits; and (3) all elements are polygonal and closely fitting. Unlike most baracromians (Stenopterygius cayi, S. aalensis and ophthalmosaurids; Motani, 2005; Fischer et al. 2011, 2012; Maxwell, Fernández \& Schoch, 2012), MNHN AC 9950 possesses flattened paddle elements. This is not an effect of diagenesis since the specimen appears to be preserved in three dimensions.

MNHN AC 9951: Both coracoids are preserved. As in Ichthyosaurus and some shastasaurids (Nicholls \& Manabe, 2001), the coracoid possesses large anterior and posterolateral notches, giving it the shape of a fan. The transverse bar of the interclavicle is short and roun$\mathrm{ded}$, as in some Ichthyosaurus specimens (personal observation by V.F. on NHMUK material). Both clavicles are present but lack distinguishing or remarkable features. As in MNHN AC 9950, the forefin is typical for Ichthyosaurus. The humerus is short and stout, as in Excalibosaurus, Eurhinosaurus (McGowan, 2003) and Suevoleviathan (Maisch, 1998). A wide crest, presumably the deltopectoral crest, is present as in thunnosaurians (McGowan \& Motani, 2003). The radius and the ulna are large, pentagonal and lack a spatium interosseum, unlike in Leptonectes tenuirostris (e.g. Godefroit, 1992). Two digits arise from the intermedium ('latipinnate' architecture). A supplementary 'internal' digit is present between the second and third digit, starting at the level of carpals. A supplementary posterior digit is also present, giving a total of six digits at the level of metacarpals. The forefin is markedly long, as in some specimens of Ichthyosaurus (Motani, 1999a; McGowan \& Motani, 2003). The fourth natural digit possesses more than 21 phalanges.

Identification: The combination of a 'latipinnate' architecture of both forefins and of a secondary digital subdivisions is unique for Ichthyosaurus (Motani, 1999a). However, all species currently within this genus share a similar forefin architecture (e.g. McGowan \& Motani, 2003). One exception is Ichthyosaurus conybeari, where notches on the leading edge of the forefin are present (McGowan \& Motani, 2003) unlike in MNHN AC 9950 and MNHN AC 9951. However, the presence of notches appears related to ontogeny in ichthyosaurs, being considered by Johnson (1977) as an adult feature. Because it is difficult to assess the ontogenetic age of MNHN AC 9950 and MNHN AC 9951, this criterion cannot be used here. Accordingly, both specimens are referred to Ichthyosaurus sp.

\section{3.b. Plesiosaurs}

Systematic Palaeontology

Sauropterygia Owen, 1860

Plesiosauria Blainville, 1835

Plesiosauroidea Gray, 1825

Plesiosauridae Gray, 1825

Plesiosaurus De la Beche \& Conybeare, 1821

Plesiosaurus dolichodeirus De la Beche \& Conybeare, 1824

Referred specimen: MNHN AC 8592, a partial postcranial skeleton (Fig. 3c); and MNHN AC 8581, a partial mandible (Fig. 3d, e).

Remark: MNHN AC 8592 was referred to Plesiosaurus by Cuvier (1825, p. 357, pl. III, fig. 1) and MNHN AC 8581 to Plesiosaurus dolichodeirus by Gaudry (1890, p. 191, fig. 279).

Description: MNHN AC 8592: A partial skeleton preserved in articulation and comprising an almost entire post-cranium lacking most of the neck. It includes 56 vertebrae, most of the pectoral and pelvic girdles and most of the limbs. A full description was provided by Vincent \& Taquet (2010).

MNHN AC 8581: A mandible including the nearly complete left and right dentaries. Because the preserved fragments of the left and right dentary are of equal length, it is reasonable to believe that they disarticulated from the posterior elements of the mandibular ramus rather than being fractured at this point. No teeth are preserved in association with this specimen. Nineteen alveoli are discernable on each dentary. The first six alveoli are the largest. The mandibular symphysis is $2.3 \mathrm{~cm}$ long and occupies between two and four tooth positions. Primary and secondary alveoli and the lateral groove are well developed in the anterior region of the jaw. The lateral groove and the primary alveoli become indistinct behind the position of the last enlarged tooth in each ramus (the sixth one).

Identification: MNHN AC 8592 was referred to Plesiosaurus dolichodeirus by Storrs (1997) and Vincent \& Taquet (2010). In MNHN AC 8581, the lower jaw symphysis is not reinforced and resembles the simple symphysis seen in Plesiosaurus dolichodeirus (Storrs, 1997) and Plesiopterys wildi (O'Keefe, 2004). The mandible is slightly constricted at the level of the sixth dentary tooth as in Futabasaurus (Sato, Hasegawa \& Manabe, 2006). This mandible is morphologically similar to that found in the more complete specimens of Plesiosaurus dolichodeirus as proposed by Gaudry (1890) who referred it to this taxon. Examination of the former catalogue of the fossil vertebrates in the MNHN collections (Anonymous, unpub. report, 1861) revealed that MNHN AC 8581 'se trouvait avec le squelette, plus bas indiqué, donné par Mr. Constant Prévost; No. 8592' ('was found with the skeleton, indicated below, given by Mr. Constant Prévost; No. 8592', author translation). Despite the ambiguous phrasing, MNHN AC 
8581 and 8592 might therefore have belonged to the same individual. This is congruent with the anatomy and the proportions of these two specimens.

\section{Discussion}

The mosasaur skull that Cuvier had extensively described some years before (Cuvier, 1808) was one of the few fossil of marine reptiles that he had at his disposal when he wrote the first edition of his 'Recherches sur les Ossemens fossiles' (Cuvier, 1812). The discovery and description of the first fairly complete plesiosaurs and ichthyosaurs from England (De la Beche \& Conybeare, 1821 ) and the purchase of marine reptiles from the Dorset coast allowed him to complete his inventory by adding, in his new edition of the 'Recherches sur les Ossemens fossiles' (1824), a fifth chapter entitled De l'Ichthyosaurus et du Plésiosaurus. Cuvier realized that the new fossil reptiles had major implications for our understanding of the distant past: their unexpected combination of anatomical structures, inferred lifestyle and the associated faunal successions provided a perfect illustration to his revolutions of the globe.

'Ce qu'il est impossible de ne pas reconnoître comme une vérité désormais constante, c'est cette multitude, cette grandeur et cette variété surprenante des reptiles qui habitoient les mers ou qui couvroient la surface du globe à cette époque antique où se sont déposées les couches vulgairement désignées par le nom beaucoup trop restreint de terrains $d u$ Jura; dans des lieux et des pays immenses où non seulement l'homme n'existoit pas, mais où, s'il y avoit des mammifères, ils étoient tellement rares, qu'à peine peut-on en citer un ou deux fragments' (Cuvier, 1824, p. 486-487). 'What is impossible not to acknowledge as steady truth anymore, is this multitude, this greatness and this surprising variety of reptiles which inhabited the seas or that covered the globe at this antique time where layers designated by the too restricted name of terrain of Jura were deposited; in places and immense countries where not only man did not existed, but where, if there were mammals, they were so rare that we can just mention one or two fragments' (author translation).

Georges Cuvier was not only interested in comparative anatomy but also in the succession of species on Earth. Well before the Cenozoic fossil mammals, ichthyosaurs, plesiosaurs and mosasaurs were not only additional witnesses of the Earth's antiquity, but also served as a fundamental basis for elaborating and supporting his - then ground-breaking - catastrophist theories (see Bardet \& Jagt 1996, p. 587-588 for details). Among other things, Cuvier argued from the existence of Mesozoic marine reptiles to conclude his 'Discours sur les révolutions de la surface du globe' that:

'Ce qui est certain, c'est que nous sommes maintenant au moins au milieu d'une quatrième succession d'animaux terrestres, et qu'après l'âge des reptiles, après celui des paleotheriums, après celui des mammouths, des mastodontes et des megatheriums, est venu l'âge où l'espèce humaine, aidée de quelques animaux domestiques, domine et féconde paisiblement la Terre" (Cuvier, 1825, p. 353). 'What is certain is that we are now in the midst of at least the fourth succession of terrestrial animals, and that after the age of reptiles, after that of paleotheriums, after that of mammoths, mastodons and megatheriums, came the age when the human species, aided by a few domestic animals, dominates and fecondate peacefully the Earth' (author translation).

The marine reptile specimens acquired by Cuvier during the Bullock auction are all ichthyosaurs. This is not surprising, since most large vertebrate remains from Lyme Regis belong to this group (Lord \& Davis, 2010; Vincent, 2012). The ichthyosaurs found by Mary Anning that were available for Cuvier's anatomical studies belong to two different genera: the basal neoichthyosaurian Leptonectes and the basal thunnosaurian Ichthyosaurus. Eight genera are currently known from the Lower Jurassic (Ichthyosaurus, Leptonectes, Eurhinosaurus, Excalibosaurus, Suevoleviathan, Stenopterygius, Hauffiopteryx and Temnodontosaurus; Maisch \& Matzke, 2000a), of which three are recognized in the lower Lias Group (Ichthyosaurus, Leptonectes and Temnodontosaurus). During Cuvier's time there was only a single recognized genus from the Lower Jurassic (Ichthyosaurus) with four constituent species, I. tenuirostris, I platyodon, I. communis and I. intermedius, that were known from the Lower Lias. Subsequently, I. tenuirostris and I platyodon were placed in Leptonectes and Temnodontosaurus, respectively. The specific diversity of the lower Lias Group ichthyosaurs was therefore already established at that time. On the contrary, Cuvier and his contemporaries knew only one plesiosaur species (Plesiosaurus dolichodeirus); this was far from reflecting the lower Lias Group plesiosaur diversity along the Dorset coast, which is currently represented by four genera (Plesiosaurus, Archaeonectrus, Anningasaura and Attenborosaurus) and as many species.

The Muséum National d'Histoire Naturelle in Paris possesses many other marine reptile remains from Lyme Regis. Most of them were presented by Buckland and Conybeare. Buckland often visited Lyme Regis during his vacations and was frequently seen hunting fossils together with Mary Anning. It therefore appears likely that some of these remains may have been found by both of these famous fossilists, and then sent to Cuvier by Buckland. Accordingly, these specimens (currently under study) likely constitute another part of Mary Anning's legacy to French vertebrate palaeontology.

Acknowledgements. We warmly thank R. Allain and V. Pernègre (Muséum national d'Histoire naturelle, Paris) for providing access to the collections of the MNHN. Special thanks are due to V. Pernègre for rediscovering and skilfully restoring MNHN AC 9937. We also thank S.D. Chapman and P.M Barrett (Natural History Museum, London) for providing access to the collections of NHMUK and J.A. Massare, D.R. Lomax and W.R. Wahl for fruitful discussions and observations on Ichthyosaurus during V.F.'s stay at the NHMUK. We are very grateful to H.S. Torrens (Keele University, UK) for numerous discussions and for helping with important historical information. J.F. and P.V. are grateful to M. Evans (New Walk Museum and Art Gallery, Leicester, UK) and M.A. Taylor (University of Bristol, UK) for historical discussions. 
We thank B.P. Kear (Uppsala Universitet, Sweden) for helpful comments and inviting us to contribute to this special issue. We are grateful to M.J. Benton (University of Bristol, UK), P.M. Barrett (Natural History Museum, London, UK) and an anonymous reviewer for helpful comments that greatly improved the quality of this paper. P.V. acknowledges financial support from the Alexander von Humboldt Foundation. V.F. is an Aspirant du Fond National de la Recherche Scientifique (F.R.S.-FNRS).

\section{Declaration of interest}

None.

\section{References}

ANONYMOUS, 1824. Provincial occurrences in the counties of England, arranged alphabetically. The New Monthly Magazine and Journal 12, 92-6.

ApPlebY, R. M. 1979. The affinities of Liassic and later ichthyosaurs. Palaeontology 22, 921-46.

BARDET, N. \& JAGT, J. W. M. 1996. Mosasaurus hoffmanni, le "Grand Animal Fossile des Carrières de Maestricht": deux siècles d'histoire. Bulletin du Muséum National d'Histoire Naturelle, Paris, Section C 18, 586-93.

Bennett, S. P., BARrett, P. M., Collinson, M. E., MoOreFaY, S., DaVis, P. G. \& Palmer, C. P. 2012. A new specimen of Ichthyosaurus communis from Dorset, UK, and its bearing on the stratigraphical range of the species. Proceedings of the Geologists' Association 123, 146-54.

Benton, M. J. \& Spencer, P. S. 1995. Fossil reptiles of Great Britain. Geological Conservation Review Series 10, 1-386.

BlainVILle, H. M. D. DE. 1835. Description de quelques espèces de reptiles de la Californie, précédée de l'analyse d'un système général d'érpetologie et d'amphibiologie. Nouvelles Annales du Muséum d'Histoire Naturelle, Paris 4, 233-96.

CAine, H. \& Benton, M. J. 2011. Ichthyosauria from the upper Lias of Strawberry Bank, England. Palaeontology 54, 1069-93.

CONYBEARE, W. D. 1822. Additional notices on the fossil genera Ichthyosaurus and plesiosaurus. Transactions of the Geological Society of London - Series 2 1, 103-23.

CONYBEARE, W. D. 1824. On the discovery of an almost perfect skeleton of the Plesiosaurus. Transactions of the Geological Society of London - Series 2 1, 381-9.

Cope, J. C. W., GetTy, T. A., Howarth, M. K., Morten, N. \& TORRENS, H. S. 1980. A correlation of Jurassic rocks of the British Isles. Part 1. Geological Society of London Special Reports 14, 1-73.

CuviER, G. 1808. Sur le grand animal fossile des carrières de Maestricht. Annales du Muséum d'Histoire Naturelle, Paris 12, 145-76.

CUVIER, G. 1812. Recherches sur les ossemens fossiles de quadrupèdes, où l'on rétablit les caractères de plusieurs espèces d'animaux que les révolutions du globe paroissent avoir détruites. Paris: Deterville, 350 pp.

CUVIER, G. 1824. Recherches sur les ossemens fossiles, où l'on rétablit les caractères de plusieurs animaux dont les révolutions du globe ont détruit les espèces. 2nd edition. Tome cinquième, Deuxième partie, contenant les ossemens de reptiles et le résumé général. Paris \& Amsterdam: Dufour \& d'Ocagne, $547 \mathrm{pp}$.

CUVIER, G. 1825. Discours sur les révolutions de la surface du globe, et sur les changemens qu'elles ont produits dans le règne animal. 3rd edition. Paris: Dufour \& d'Ocagne, $400 \mathrm{pp}$.
CUVIER, G. 1836. Recherches sur les ossemens fossiles de quadrupèdes, où l'on rétablit les caractères de plusieurs espèces d'animaux que les révolutions du globe paroissent avoir détruites. 4th edition. Tome dixième. Paris: Dufour \& d'Ocagne, $503 \mathrm{pp}$.

De la Beche, H. T. \& Conybeare, W. D. 1821. Notice of the discovery of a new fossil animal, forming a link between the Ichthyosaurus and crocodile, together with general remarks on the osteology of the Ichthyosaurus. Transactions of the Geological Society of London 5, 559-94.

Druckenmiller, P. S., Hurum, J., Knutsen, E. M. \& NAKREM, H. A. 2012. Two new ophthalmosaurids (Reptilia: Ichthyosauria) from the Agardhfjellet Formation (Upper Jurassic: Volgian/Tithonian), Svalbard, Norway. Norwegian Journal of Geology 92, 311-39.

DruCKENMILleR, P. S. \& MAXWELl, E. E. 2010. A new Lower Cretaceous (lower Albian) ichthyosaur from the Clearwater Formation, Alberta, Canada. Canadian Journal of Earth Sciences 47, 1037-53.

FernÁNDEZ, M. S., ARChUby, F., TAlevi, M. \& EBNER, R. 2005. Ichthyosaurian eyes: paleobiological information content in the sclerotic ring of Caypullisaurus (Ichthyosauria, Ophthalmosauria). Journal of Vertebrate Paleontology 25, 330-7.

Fischer, V., APPleBY, R. M., NAISH, D., Liston, J., RIDING, J. B., BRIndLey, S. \& Godefroit, P. 2013. A basal thunnosaurian from Iraq reveals disparate phylogenetic origins for Cretaceous ichthyosaurs. Biology Letters 9 , 20130021.

Fischer, V., MAisch, M. W., NAish, D., Liston, J., Kosma, R., JOGER, U., KRÜGER, F. J., PARDO-PÉREZ, J., TAINSH, J. \& APPLEBY, R. M. 2012. New ophthalmosaurids from the Early Cretaceous of Europe demonstrate extensive ichthyosaur survival across the Jurassic-Cretaceous boundary. PLOS ONE 7, e29234, published online 3 January 2012, doi:10.1371/journal.pone.0029234.

Fischer, V., MASure, E., ARKhangelsky, M. S. \& GodefroIT, P. 2011. A new Barremian (Early Cretaceous) ichthyosaur from western Russia. Journal of Vertebrate Paleontology 31, 1010-25.

FRAAS, E. E. 1891. Ichthyosaurier der Süddeutschen Trias und Jura-Ablagerungen. Tübingen: H. Laupp, 81pp.

GAUDRY, A. J. 1890. Les enchaînements du monde animal dans les temps géologiques. Fossiles secondaires. Paris: Savy, 323 pp.

GODEFROIT, P. 1992. Présence de Leptopterygius tenuirostris (Reptilia, Ichthyosauria) dans le Lias moyen de Lorraine belge. Bulletin de l'Institut Royal des Sciences Naturelles de Belgique Sciences de la Terre 62, 163-70.

Godefroit, P. 1993a. The skull of Stenopterygius longifrons (Owen, 1881). Dinosaurs and other fossil reptiles of Europe: Second Georges Cuvier Symposium, Montbeliard (France), September 8.11.1992. Revue de Paléobiologie de Genève, Volume spécial 7, 67-84.

GODEFROIT, P. 1993b. Les grands ichthyosaures sinémuriens d'Arlon. Bulletin de l'Institut Royal des Sciences Naturelles de Belgique Sciences de la Terre 63, 2571.

GoDEFROIT, P. 1994. Les reptiles marins du Toarcien (Jurassique inférieur) belgo-luxembourgeois. Mémoires pour servir à l'Explication des Cartes Géologiques et Minières de la Belgique 39, 1-98.

GODEFROIT, P. 1996. Un crâne d'Ichthyosaurus communis (Reptilia, Ichthyosauria) du Sinémurien supérieur de Lorraine belge. Bulletin de la Société Belge de Géologie 104, 77-89.

Gosselet, J. 1896. Constant Prévost: coup d'œil rétrospectif sur la géologie en France pendant la première moitié du 
XIXè siècle. Annales de la Société Géologique du Nord 25, 1-345.

GRAY, J. E. 1825. A synopsis of the genera of Reptiles and Amphibia, with a description of some new species. Annals of Philosophy, New Series 10, 193-217.

HoME, E. 1814. Some account of the fossil remains of an animal more nearly allied to fishes than any of the other classes of animals. Philosophical Transactions of the Royal Society of London 104, 571-7.

HOME, E. 1819a. An account of the fossil skeleton of the Proteo-Saurus. Philosophical Transactions of the Royal Society of London 109, 209-11.

HoME, E. $1819 b$. Reasons for giving the name Proteo-Saurus to the fossil skeleton which has been described. Philosophical Transactions of the Royal Society of London 109, 212-6.

HUENE, F. VON. 1922. Die Ichthyosaurier des Lias und ihre Zusammenhänge. Berlin: Gebrüder Borntraeger, 114 pp.

HUENE, F. VON. 1951. Ein neuer Fund von Eurhinosaurus longirostris. Neues Jahrbuch für Geologie und Paläontologie, Abhandlungen 93, 277-83.

JOHNSON, R. 1977. Size independent criteria for estimating relative age and the relationship among growth parameters in a group of fossil reptiles (Reptilia: Ichthyosauria). Canadian Journal of Earth Sciences 14, 1916-24.

JOHNSON, R. 1979. The osteology of the pectoral complex of Stenopterygius Jaekel (Reptilia: Ichthyosauria). Neues Jarhbuch für Geologie und Paläontologie, Abhandlungen 159, 111-27.

KEAR, B. P. \& ZAMMIT, M. 2013. In utero foetal remains of the Cretaceous ichthyosaurian Platypterygius: ontogenetic implications for character state efficacy. Geological Magazine 151, 71-86.

LHWYD, E. 1699. Lithophylacii Britannici Ichnographia. Sive Lapidum aliorumque Fossilium Britannicorum singulari figura insignium, quotquot hactenus vel ipse invenit vel ab amicis accepit, Distributio Classica: Scrinii sui lapidarii Repertorium cum locis singulorum natalibus exhibens. Additis rariorum aliquot figuris aere incisis; cum Epistolis ad Clarissimos Viros de quibusdam circa marina Fossilia \& Stirpes minerales praesertim notandis. ex Officina M. C.: London, 139 pp.

Lomax, D. R. 2010. An Ichthyosaurus (Reptilia, Ichthyosauria) with gastric contents from Charmouth, England: first report of the genus from the Pliensbachian. Paludicola 8, 22-36.

LORD, A. R. \& DAVIS, P. G. 2010. The Palaeontological Association Field Guide to Fossils, Fossils from the Lower Lias of the Dorset Coast. Wiley: London, 436 pp.

MAISCH, M. W. 1997a. A case against a diapsid origina of the Ichthyosauria. Neues Jarhbuch für Geologie und Paläontologie, Abhandlungen 205, 111-27.

MAISCH, M. W. 1997b. The cranial osteology of Ichthyosaurus intermedius Conybeare, 1822 from the Lias of Great Britain. Stuttgarter Beiträge zur Naturkunde Serie $B$ (Geologie und Paläontologie) 258, 1-27.

MAISCH, M. W. 1998. A new ichthyosaur genus from the Posidonia Shale (Lower Toarcian, Jurassic) of Holzmaden, SW Germany with comments on the phylogeny of post-Triassic ichthyosaurs. Neues Jahrbuch für Geologie und Paläontologie, Abhandlungen 209, 47-78.

MAISCH, M. W. 2001. Neue Exemplare der seltenen Ichthyosauriergattung Suevoleviathan Maisch 1998 aus dem Unteren Jura von Südwestdeutschland. Geologica et $\mathrm{Pa}$ laeontologica 35, 145-60.

MAISCH, M. W. 2002. A braincase of Temnodontosaurus cf. trigonodon (von Theodori, 1843) (Ichthyosauria) from the Lower Jurassic of Germany. Geologica et Palaeontologica 36, 115-22.

MAISCH, M. W. 2008. Revision der Gattung Stenopterygius Jaekel, 1904 emend. von Huene, 1922 (Reptilia: Ichthyosauria) aus dem unteren Jura Westeuropas. Palaeodiversity 1, 227-71.

MAISCH, M. W. 2010. Phylogeny, systematics, and origin of the Ichthyosauria - the state of the art. Palaeodiversity 3, 151-214.

Maisch, M. W. \& Ansorge, J. 2004. The Liassic ichthyosaur Stenopterygius cf. S. quadrissicus from the lower Toarcian of Dobbertin (NE Germany) and some considerations on lower Toarcian marine reptile palaeobiogeography. Paläontologische Zeitschrift 78, 161-71.

Maisch, M. W. \& HungerbüHLER, A. 1997. Revision of Temnodontosaurus nuertingensis (v. Huene, 1931), a large ichthyosaur from the Lower Pliensbachian (Lower Jurassic) of Nürtingen, South Western Germany. Stuttgarter Beiträge zur Naturkunde Serie B (Geologie und Paläontologie) 248, 1-11.

MAisch, M. W. \& HungerbüHLER, A. 2001. New evidence for a discrete supratemporal bone in the Jurassic Ichthyosaur Temnodontosaurus. Historical Biology 15, 335-45.

MAISCH, M. W. \& MATZKE, A. T. 2000a. The Ichthyosauria. Stuttgarter Beiträge zur Naturkunde Serie B (Geologie und Paläontologie) 298, 1-159.

MAISCH, M. W. \& MATZKE, A. T. 2000b. New data on the cranial osteology of Ichthyosaurus communis Conybeare, 1822. Geologica et Palaeontologica 34, 137-43.

MaIsCH, M. W. \& MATZKE, A. T. 2002. The skull of a large Lower Triassic ichthyosaur from Spitzbergen and its implications for the origin of the Ichthyosauria. Lethaia $\mathbf{3 5}$, 250-6.

MAISCH, M. W. \& MATZKE, A. T. 2003. The cranial osteology of the ichthyosaur Leptonectes cf. tenuirostris from the Lower Jurassic of England. Journal of Vertebrate Paleontology 23, 116-27.

MAisch, M. W. \& ReISDORF, A. G. 2006. Evidence for the longest stratigraphic range of a post-Triassic ichthyosaur: a Leptonectes tenuirostris from the Pliensbachian (Lower Jurassic) of Switzerland. Geobios 39, 491505.

Maisch, M. W., Reisdorf, A., Schlatter, R. \& Wetzel, A. 2008. A large skull of Ichthyosaurus (Reptilia: Ichthyosauria) from the Lower Sinemurian (Lower Jurassic) of Frick (NW Switzerland). Swiss Journal of Geoscience 101, 617-27.

MANTELL, G. 1829. A tabular arrangement of the organic remains of the County of Sussex. Transactions of the Geological Society of London 2(3), 201-16.

MANTELl, G. A. 1846. A few notes on the prices of fossils. London Geological Journal 1, 13-7.

Martin, J. E., Fischer, V., Vincent, P. \& SuAn, G. 2012. A longirostrine Temnodontosaurus (Ichthyosauria) with comments on Early Jurassic ichthyosaur niche partitioning and disparity. Palaeontology 55, 995-1005.

MASSARE, J. A. 1987. Tooth morphology and prey preference of Mesozoic marine reptiles. Journal of Vertebrate Paleontology 7, 121-37.

Massare, J. A. \& LomaX, D. R. 2013. An Ichthyosaurus breviceps collected by Mary Anning: new information on the species. Geological Magazine 151, 21-8.

MAXWELl, E. E. 2012. New metrics to differentiate species of Stenopterygius (Reptilia: Ichthyosauria) from the Lower Jurassic of southwestern Germany. Journal of Paleontology 86, 105-15. 
Maxwell, E. E., Caldwell, M. W. \& LamoureuX, D. O. 2011. Tooth histology in the Cretaceous ichthyosaur Platypterygius australis, and its significance for the conservation and divergence of mineralized tooth tissues in amniotes. Journal of Morphology 272, 129-35.

MaXwell, E. E., Caldwell, M. W. \& LamoureuX, D. O. 2012. Tooth histology, attachment, and replacement in the Ichthyopterygia reviewed in an evolutionary context. Paläontologische Zeitschrift 86, 1-14.

MaXwell, E. E. \& DrucKenMiller, P.S. 2011. A small ichthyosaur from the Clearwater Formation (Alberta, Canada) and a discussion of the taxonomic utility of the pectoral girdle. Paläontologische Zeitschrift 85, 457-63

MAXWELl, E. E., FERnÁNDEZ, M. S. \& SCHOCH, R. R. 2012. First diagnostic marine reptile remains from the Aalenian (Middle Jurassic): a new ichthyosaur from southwestern Germany. PLOS ONE 7, e41692, published online 1 August 2012, doi: 10.1371/journal.pone.0041692.

MCGowAN, C. 1973. The cranial morphology of the Lower Liassic latipinnate ichthyosaurs of England. Bulletin of the British Museum (Natural History) Geology 24, 1109.

MCGOWAN, C. 1974a. A revision of the longipinnate ichthyosaurs of the Lower Jurassic of England, with description of the new species (Reptilia, Ichthyosauria). Life Science Contributions, Royal Ontario Museum 97, 1-37.

MCGowAN, C. 1974b. A revision of the latipinnate ichthyosaurs of the Lower Jurassic of England (Reptilia, Ichthyosauria). Life Science Contributions, Royal Ontario Museum 100, 1-30.

MCGowAN, C. 1979. A revision of the Lower Jurassic ichthyosaurs of Germany with descriptions of two new species. Palaeontographica. Abteilung A. Paläozoologie, Stratigraphie 166, 93-135.

MCGOWAN, C. 1994. Temnodontosaurus risor is a juvenile of T. platyodon (Reptilia: Ichthyosauria). Journal of Vertebrate Paleontology 14, 472-9.

MCGOWAN, C. 1996. Giant ichthyosaurs of the Early Jurassic. Canadian Journal of Earth Sciences 33, 1011-21.

McGowAN, C. 2003. A new specimen of Excalibosaurus from the English Lower Jurassic. Journal of Vertebrate Paleontology 23, 950-6.

McGowan, C. \& Milner, A. 1999. A new Pliensbachian ichthyosaur from Dorset, England. Palaeontology 42, 761-8.

McGowan, C. \& Motani, R. 2003. Ichthyopterygia. In Handbook of Paleoherpetology 8 (ed. H.-D. Sues), 173 pp, München: Pfeil.

MOTANI, R. 1999a. On the evolution and homologies of ichthyosaurian forefins. Journal of Vertebrate Paleontology 19, 28-41.

MotANI, R. 1999b. Phylogeny of the Ichthyopterygia. Journal of Vertebrate Paleontology 19, 473-96.

MotANI, R. 2005. True skull roof configuration of Ichthyosaurus and Stenopterygius and its implications. Journal of Vertebrate Paleontology 25, 338-42.

Nicholls, E. L. \& MANABE, M. 2001. A new genus of ichthyosaur from the Late Triassic Pardonet Formation of British Columbia: bridging the Triassic Jurassic gap. Canadian Journal of Earth Sciences 38, 983-1002.

O'KeEFe, R. F. 2004. Preliminary description and phylogenetic position of a new plesiosaur (Reptilia: Sauropterygia) from the Toarcian of Holzmaden, Germany. Journal of Paleontology 78, 973-88.
OwEN, R. 1860. On the orders of fossil and recent Reptilia, and their distribution in time. Report of the British Association for the Advancement of Science for 1859 29,153-66.

Reisdorf, A. G., Maisch, M. W. \& Wetzel, A. 2011. First record of the leptonectid ichthyosaur Eurhinosaurus longirostris from the Early Jurassic of Switzerland and its stratigraphic framework. Swiss Journal of Geosciences 104, 211-24.

SANDER, P. M. 2000. Ichthyosauria: their diversity, distribution, and phylogeny. Paläontologische Zeitschrift 74, $1-35$.

SAnder, P. M., Chen, X., Cheng, L. \& WAng, X. 2011. Short-snouted toothless ichthyosaur from China suggests Late Triassic diversification of suction feeding ichthyosaurs. PLOS ONE 6, e19480, published online 1 August 2012, doi: 10.1371/journal.pone.0019480.

Sato, T., Hasegawa, Y. \& Manabe, M. 2006. A new elasmosaurid plesiosaur from the Upper Cretaceous of Fukushima, Japan. Palaeontology 49, 467-84.

SCHEUCHZER, J. J. 1708. Piscium querelae et vindiciae. Gessner: Zürich, $36 \mathrm{pp}$.

SEELEY, H. G. 1880. On the skull of an Ichthyosaurus from the Lias of Whitby, apparently indicating a new species (I. zetlandicus, Seeley), preserved in the Woodwardian Museum of the University of Cambridge. Quarterly Journal of the Geological Society, 635-47.

StORRS, G. W. 1997. Morphological and taxonomic clarification of the genus Plesiosaurus. In Ancient marine reptiles (eds J. M. Callaway \& E. L. Nicholls), pp. 145190. San Diego: Academic Press.

STUKELY, W. 1719. An account of the impression of the almost entire sceleton of a large animal in a very hard stone, lately presented to the Royal Society, from Nottinghamshire. Philosophical Transactions of the Royal Society 30, 963-8.

TAQUET, P. 2003. Quand les reptiles marins anglais traversaient la Manche: Mary Anning et Georges Cuvier, deux acteurs de la découverte et de l'étude des ichthyosaures et des plésiosaures. Annales de Paléontologie 89, 37-64.

THEODORI, C. 1843. Über einen kolossalen Ichthyosaurus trigonodon. Gelehrte Anzeigen der Königlich Bayerischen Akademie der Wissenschaften, München 16, 906-11.

TORRENS, H. 1979. Colonel Birch (c. 1768 - 1829). Newsletter of the Geological Curators Group 2, 405-11.

TORRENS, H. 1995. Presidential Address: Mary Anning (1799-1847) of Lyme; "the greatest fossilist the world ever knew". British Journal of the History of Science 28, 257-84.

VERSTEGAN, R. 1605. Restitution of Decayed Intelligence in Antiquities, Concerning the Most Noble and Renowned English Nation. Bruney: Antwerp, 338 pp.

VINCENT, P. 2012. Re-description of a basal plesiosaur (Reptilia, Sauropterygia) from the Lower Jurassic of England. Journal of Paleontology 86, 167-76.

VINCENT, P. \& TAQUET, P. 2010. A plesiosaur specimen from the Lias of Lyme Regis: the second ever discovered plesiosaur by Mary Anning. Geodiversitas 32, 37790.

WignAll, P. B. \& HALlaM, A. 1991. Biofacies, stratigraphic distribution and depositional models of British onshore Jurassic black shales. In Modern and Ancient Continental Shelf Anoxia (eds R. V. Tyson and T. H. Pearson), pp. 291-309. Geological Society, London, Special Publication no. 58. 